Windle, J. (2013). 'How the East Influenced Drug Prohibition'. The International History Review, 35(5), pp. 1185-1199. Pre-publication copy

\title{
How the East Influenced Drug Prohibition
}

\author{
James Windle ${ }^{1}$ \\ The final version of the paper as published in the print edition can be found \\ at:http://www.tandfonline.com/doi/abs/10.1080/07075332.2013.820769?journalCode=rinh20 \\ \#.VaZdF_mJeeM
}

${ }^{1}$ School of Law and Social Sciences, University of East London

\begin{abstract}
In much of the academic literature drug prohibition is often described as an American, or at least a Western, construct. This paper shows how prohibitions were enforced in Asian countries while the United States and Western Europe were routinely trading opium. The concept of prohibition being a distinctly American construct is, therefore, flawed. Furthermore, Western missionaries to China are often credited as important actors in the formulation of Western prohibitions. These missionaries may, however, have been influenced by the prohibitionist ideals of the peoples they were trying to convert to Christianity. This paper does not dispute the importance of American pressure on the global spread of prohibition but rather seeks to add balance to its historiography, by elucidating how Western prohibitions were pre-dated, and possibly influenced, by Eastern prohibitions.
\end{abstract}


Windle, J. (2013). 'How the East Influenced Drug Prohibition'. The International History Review, 35(5), pp. 1185-1199. Pre-publication copy

\section{Introduction}

In much of the academic literature drug prohibition is often described as an American, or at least a Western, construct. This article shows how prohibitions were enforced in Asian countries while the United States and Western Europe were routinely trading opium. The concept of prohibition being a distinctly American construct is, therefore, flawed. The second part of the article evaluates the potential influence Eastern prohibitionists had upon Western missionaries, who are often credited as important actors in the formulation of prohibition in the West.

This article does not dispute the importance of the United States and Western European countries in renovating prohibition to conform to a more globalised world. While the United States may not have constructed prohibition, it did globalise its prohibitionist policies and the preventive measures it employs against drugs. ${ }^{1}$ It may even be that global prohibition is a 'US dream', ${ }^{2}$ however, this is not the same as national prohibition being an American construct. By showing how Western prohibitions were pre-dated, and possibly influenced by, Eastern prohibitions this article will provide a more nuanced perspective on both global and national prohibitions, thus adding balance to the historiography of prohibition.

The first section provides the central arguments of what could be termed the 'prohibition as an American construct' thesis. This is followed by six case studies detailing the origins of prohibitions of opium and opiates in: the United States; Siam (Thailand); Burma; Japan; Viet Nam; and China. The article focuses primarily on opium and opiate prohibitions, as it was the first drug of international concern and the impetus to the current international drug-control regime. The final section discusses the potential influence Chinese prohibitionists had upon Western missionaries, who in turn influenced Western prohibitions.

\section{The 'prohibition as a US construct' thesis}

Ethan Nadelmann, one of the principle proponents of the 'prohibition as an American construct' thesis, argues that norms forming the foundation of the global drugsprohibition regime are rooted in Western Europe and the United States. ${ }^{3}$ That is, international legal regulations governing what is globally considered acceptable/deviant have been driven by the morality of Western Europe and the United States: 
Windle, J. (2013). 'How the East Influenced Drug Prohibition'. The International History Review, 35(5), pp. 1185-1199. Pre-publication copy

[T]he nature of the global drug control regime reflected the predominance of the United States and Europe in establishing global norms concerning the selection and appropriate uses of psychoactive substances. Some Asian states, for instance, might have opted for a different global regime that legitimized the use of opium [however] ... the global drug enforcement regime reflected the desire and capacity of the United States to impose its drug-related norms on the rest of the world. ${ }^{4}$

For Nadelmann, global regimes begin life with 'moral entrepreneurs' in one country mobilising popular and political support for their idea. They then communicate and co-operate with moral entrepreneurs in other countries, possibly joining together to persuade foreign audiences that their prohibition is cosmopolitan rather than national. ${ }^{5}$

The global drug-prohibition regime was influenced heavily by moral entrepreneurs in nineteenth-century Britain and the United States, including religious missionaries who had lived and worked in China. ${ }^{6}$ The motivation for missionary opposition to opium is usually seen as a mixture of morality ${ }^{7}$ and professional selfinterest: missionaries used opium as a scapegoat for their failures to convert the Chinese to Christianity. ${ }^{8}$ As will be discussed later in the paper, some missionaries may, however, have learnt prohibition from the peoples they were trying to convert.

Many missionaries formed, or supported, groups of moral entrepreneurs in the United States and the United Kingdom to lobby Western countries to cease exporting opium to China, ${ }^{9}$ the assumption being that reducing the availability of opium would prevent consumption. ${ }^{10}$ Arnold Taylor suggests that their role was important in:

... evoking the inauguration of the [anti-opium] movement, and in promoting the early work once the movement had been started, that in its early stages the international campaign might quite appropriately be referred to as a missionary movement or better still, as missionary diplomacy. ${ }^{11}$ 
Windle, J. (2013). 'How the East Influenced Drug Prohibition'. The International History Review, 35(5), pp. 1185-1199. Pre-publication copy

Gregory Blue refers to them as the 'most consistent and ultimately the most influential source of opposition' to the foreign trade in, and domestic consumption of, opium. ${ }^{12}$ Missionaries provided pressure groups in the United States and the United Kingdom with evidence of the harmful effects of opium on Chinese consumers and their communities, often in the form of pamphlets, newspaper articles, sermons, or public lectures. These communications from missionaries were influential in the development of a 'compassion for China's opium-addicted masses' in the United States and Britain. ${ }^{13}$ The decision to prohibit opium in the US-controlled Philippines in 1905 was also heavily influenced by missionary sources. This said, compassion for Chinese consumers only translated into policy in the United States and Britain when it dovetailed with economic and political interests. ${ }^{14}$

The importance of opium declined during the late nineteenth century for the British, whose colony in India provided the majority of opium consumed in Asia. The crop lost much of its significance to farmers in the more modernised areas of India, resulting in many farmers voluntarily substituting opium with more profitable crops. The British Government in India had also begun to diversify its exports, constricting opium's economic significance from the $1870 \mathrm{~s}^{15}$

The United States similarly first showed its support for China's sovereign right to prohibit opium in 1887 when it banned its ships from exporting the drug to China. As the United States was attempting to gain favourable trading status from China at the time its support for prohibition dovetailed economic interests. ${ }^{16}$ The linkage of support for Chinese prohibition and national self-interest continued after 1893 when the United States began to see China as a potentially lucrative market ${ }^{17}$ for US goods and services, whilst also attempting to reduce the European dominance of trade with China. ${ }^{18}$

Additionally, in the United States and Britain, there had been a gradual shift in the perception of opium as a relatively harmless drug to be tolerated, towards one of opium as a threat to health and, thus, something to be prohibited. It was believed by many that the best way to prevent consumption in the United States and its colonies was to prevent the production of opium at the source. For this, the United States needed international support. ${ }^{19}$ In short, supporting China in their prohibition dovetailed US interest towards the end of the nineteenth century. ${ }^{20}$ 
Windle, J. (2013). 'How the East Influenced Drug Prohibition'. The International History Review, 35(5), pp. 1185-1199. Pre-publication copy

In summary, the success of moral entrepreneurs in lobbying the national and international stage was reliant upon a convergence of moral, cultural, political, and material concerns. ${ }^{21}$ As importantly, the move from national to global prohibition reflects the United States' hegemonic status: ${ }^{22}$ the United States saw global prohibition as in its best interest and possessed the influence to affect changes in foreign nations, international organisations, and international law. The following sections explore when and why prohibitions were enacted in: the United States; Burma; Japan; Siam (Thailand); Viet Nam; and China. The article then returns to the topic of moral entrepreneurs by discussing the potential effect that Chinese prohibitionists had upon Western religious missionaries.

\section{The origins of prohibition in the United States}

The first (non-alcoholic) drug prohibitions enacted in the United States were against opium smoking in San Francisco in 1875 and Virginia City (a small town in Nevada) in 1876. The first federal response to opium was enacted in 1890 when the United States levied heavy duties and restrictions on the import of opium. The 1890 regulation was limited in scope and insufficiently enforced. ${ }^{23}$ A number of individual states also began restricting the sale of opium and opiates during the $1890 \mathrm{~s}$, although many regulations were modest and contained significant loopholes. ${ }^{24}$

In 1905, the United States passed its first comprehensive opium prohibition in the Philippines, one of its colonies. Many Americans felt that the United States had a 'moral obligation to rectify what it perceived as the immoral use of narcotics' in its new colony. ${ }^{25}$ The United States, at the time, however, possessed no federal laws prohibiting or limiting the trade and consumption of opium. While prohibition on the importation of opium for smoking was passed in $1909,{ }^{26}$ prohibition on domestic distribution and sale had to wait until the 1914 Harrison Narcotics Act. ${ }^{27}$

One of the reasons for the enactment of the first federal prohibition was that the perception of opium and its derivatives had been gradually shifting from general tolerance to consumption being harmful to US society. ${ }^{28}$ David Courtwright sees this shift as resulting primarily from changes in the demographic of the consuming population: the perception of harm increased as it become less popular with middle/upper-class consumers and more popular with lower/working-class consumers. $^{29}$ 
Windle, J. (2013). 'How the East Influenced Drug Prohibition'. The International History Review, 35(5), pp. 1185-1199. Pre-publication copy

Frank Dikötter and colleagues see race as an equally important factor in the changing attitude to opium. ${ }^{30}$ There was a fear amongst some Americans - and British - that:

... opium dens in Chinatowns in Britain and the United States threatened to contaminated the West, with young white girls being ravished by sinister Orientals in these squalid places of sexual depravity and degenerate racial mixing. China was infiltrating the West, taking its revenge on its white persecutors. ${ }^{31}$

The 1875 San Francisco prohibition, for example, did not ban opium consumption, but rather opium-smoking dens, which tended to be frequented by Chinese migrants. It was, in short, 'passed against a specific form of drug use engaged in by a disreputable group that had come to be seen as threatening in lean economic times'. 32

Moral entrepreneurs (including missionaries) and professional bodies were influential in changing both popular attitudes and government policy. The medical industry lobbied for prohibition of opium partly as a means to build and secure their profession, and profits, against the self-medication of home remedies containing opium, and partly due to changing attitudes to addiction. ${ }^{33}$ There had been changes to medical opinion of addiction and the benefits/harms of opium. These changes were influenced and supported by reports from medical missionaries on the harmful effects of opium. ${ }^{34}$ Moral entrepreneurs and missionaries were also motivated by professional and economic self-interest. Many moral entrepreneurs feared that drug and alcohol consumption by the working classes would reduce economic productivity, ${ }^{35}$ while missionaries found opium a convenient scapegoat for their lack of success in converting more Chinese to Christianity.

This said, many moral entrepreneurs advocated sobriety in all its forms. ${ }^{36}$ Concerns over opium/opiate (and cocaine) consumption were a small part ${ }^{37}$ of a greater social reform movement known as the Progressive Movement. Many Progressives believed that prohibiting perceived immoral acts would change people's actions. While their most prominent campaign focused upon alcohol, they also targeted prostitution, gambling, tobacco, cocaine, and opium/opiates. ${ }^{38}$ 
Windle, J. (2013). 'How the East Influenced Drug Prohibition'. The International History Review, 35(5), pp. 1185-1199. Pre-publication copy

Alcohol was the "first drug to be the focus of a [US] mass movement that sought to eliminate its use and prohibit its production and sale'. ${ }^{39}$ The movement to restrict alcohol consumption had developed earlier than the anti-opium campaigns, during the late eighteenth century. ${ }^{40}$ Complete federal prohibition was not, however, mooted by moral entrepreneurs until the 1850s. ${ }^{41}$ This section has shown how the prohibition of opium and opiates developed during the late nineteenth century as a result of a convergence of moral and material interests driven by moral entrepreneurs and medical lobbyists.

\section{The origins of prohibition in the East}

Before Western colonial powers began facilitating the Eastern opium trade in the eighteenth century, the religious leaders of many Buddhist societies had viewed all intoxicants, including opium, as an obstacle to concentration. That is, opium was viewed as an impediment to the primary goal of the monkhood. Buddhist kings and elites followed their religious leaders' prohibitions. ${ }^{42}$ In other words, Buddhist elites throughout Asia had prohibited opium before the West had started routinely trading the drug. The following sections will provide details of five cases of opium prohibitions enforced in East and South East Asia.

\section{Thailand}

Opium was first brought to the territory which constitutes present-day Thailand by Chinese merchants in $1282 .{ }^{43}$ In 1360 , King Ramathibodi I prohibited opium consumption and trade. Offenders were paraded around the city for three days on land and three days on water. They were then jailed until detoxified and placed on probation. ${ }^{44}$ The prohibition was repeated in 1811 and 1839 , when the death penalty was introduced for trafficking. ${ }^{45}$

Prohibition lasted nearly 500 years until, in 1851, King Rama IV allowed Chinese immigrants to smoke opium. Authorised opium dens were established, consumers were registered, and the state collected revenue. ${ }^{46}$ The King also acquiesced to aggressive demands from Western nations to end the prohibition of imports by allowing foreign companies to supply the state monopoly. ${ }^{47}$ A 500-year old prohibition was partly repealed twenty-four years before the first local US opium ban and sixty-three years before the enactment of the Harrison Act. 
Windle, J. (2013). 'How the East Influenced Drug Prohibition'. The International History Review, 35(5), pp. 1185-1199. Pre-publication copy

Then in 1908 King Chulalongkorn created a state monopoly selling opium to all registered addicts, in a bid to lower consumption. ${ }^{48}$ While the majority of statesold opium was sourced from British India, ${ }^{49}$ a limited number of farmers were authorised to grow opium poppies for sale to the monopoly. Many consumers, however, continued to purchase black-market opium from Burma and the Thai highlands due to high monopoly prices. ${ }^{50}$

Between 1917 and 1920 some government leaders, including the head of the Thai Opium Department, planned to prevent lowland consumption by banning licit opium cultivation, eradicating opium poppies illicitly cultivated in the northern highlands, and interdicting smuggled Burmese opium. They were motivated by the belief that opium was having a negative impact on Thai Buddhist culture. The British Government in Burma refused to assist in the intervention as they felt it would be too expensive. ${ }^{51}$ While there were undoubtedly actors in the Thai government who would have opposed prohibition for fiscal reasons, ${ }^{52}$ the refusal may be seen as one more example of a Western nation blocking efforts to prohibit opium in Asia.

\section{Japan}

The non-medicinal consumption of opium was first prohibited in Japan during the Edo Period (1600-1867). The death penalty could be applied to those who violated the prohibition, which was considered a matter of national security. ${ }^{53}$ To limit supply the importation of opium was prohibited and in 1858, a Japanese-US trade agreement banned Americans from exporting opium to Japan. ${ }^{54}$ The prohibition continued during the Meiji Period (1868-1912) as the political elite wished to prevent Japan from what they saw as the weakening of China by opium. A Meiji regime edict in 1868 allowed for the execution of drug consumers and anyone providing a Japanese citizen with opium. ${ }^{55}$

Japan created an opium monopoly in 1897 which limited consumption and distribution. Any violation of the monopoly rules could be punished with seven years' imprisonment. To deter would-be consumers the state administered a public educational 'campaign that vilified the negative effects of opium. The campaign was successful in gaining public support for the restrictions and harsh penalties. ${ }^{, 56}$

\section{Viet Nam}


Windle, J. (2013). 'How the East Influenced Drug Prohibition'. The International History Review, 35(5), pp. 1185-1199. Pre-publication copy

Opium was prohibited 'almost as soon as it appeared', in 1665, by King Canh Tri III. The prohibition, which preceded the Harrison Act by 249 years, called for the eradication of all opium crops and stores. ${ }^{57}$

The prohibition was restated in 1820 by King Minh Mang who introduced severe punishments for consumption, including forced exile, ${ }^{58}$ and ordered sons and younger brothers of consumers to report them to the authorities. ${ }^{59}$ In 1824 the prohibition was extended by allowing for the punishment of foreign merchants and soldiers distributing or selling opium. Then in 1840 the King ordered the death sentence for ship owners smuggling opium into Viet Nam and enforced compulsory treatment programmes. ${ }^{60}$

Law-enforcement campaigns against smugglers and producers were administered until 1858, when France annexed three provinces surrounding Saigon and ordered the Emperor to pay an indemnity of 4 million silver Francs. An opium franchise was established throughout much of Viet Nam to finance the French extortion. ${ }^{61}$

Between 1858 and 1885 France gradually colonised Viet Nam. As the French took authority over an area they would immediately overturn local prohibitions and create franchises selling opium imported from British India. ${ }^{62}$ In 1899, the French constructed an opium refinery in Saigon and developed smoking opium, which burnt quicker than normal, thus encouraging consumers to smoke more. ${ }^{63}$

\section{Burma}

The Konbaung Dynasty prohibited all intoxicants and stimulants during the reign of King Bodawpaya (1781-1819), who made consumption a capital offence. Like the French, the British overturned local prohibitions as they gradually colonised parts of Burma from 1852 onwards. The original prohibition was, however, repeated in areas outside of British control by King Thibaw in 1880, six years before the British fully colonised Burma and overturned the prohibition.

Demand for opium was minimal in most newly colonised parts of Burma due to religious and cultural opposition. The British responded with an aggressive marketing campaign, which included agents distributing opium cakes to local youths and dipping betel leaves, a more popular drug, in opium. By 1841 opium consumption in British-controlled areas of Burma was higher than any province of British India. 
Windle, J. (2013). 'How the East Influenced Drug Prohibition'. The International History Review, 35(5), pp. 1185-1199. Pre-publication copy

Britain, like France in Viet Nam and other parts of Indochina, was 'responsible for the spread of opium usage'. Burma represents another example of a Western power forcing the repeal of a long-standing prohibition and being 'responsible for the spread of opium usage' ${ }^{64}$

\section{China}

While there are records indicating that opium was used in China as medicine during the eighth century, it was not until the seventeenth century that it was consumed recreationally. ${ }^{65}$ In 1729, 185 years before the United States passed the Harris Act, Emperor Yongzheng (1723-35) prohibited the sale and distribution of smoking opium. ${ }^{66}$ Possession could be punished with up to ten years imprisonment ${ }^{67}$ and 100 lashes of a bamboo cane. Merchants and opium-den operators could be sentenced to death. Opium-den employees could receive lashes of the cane and internal exile. ${ }^{68}$ The harsh punishments were a response to the belief that opium threatened the 'moral order of the "celestial dynasty"، 69

Consumption increased despite enforcement efforts. As the demand for opium grew Western merchants began exporting greater quantities. ${ }^{70}$ In 1780 China responded to increased supply and demand by prohibiting the import of opium for non-medicinal purposes. Distribution continued due to the vagueness of the definition of medicinal; consequently, in 1799 all opium imports were prohibited. The prohibition was extended to domestic opium-poppy cultivation in $1800 .^{71}$

Regardless of prohibition the British continued to produce and package Indian opium specifically for the Chinese market, which was sold at auction to private merchants who smuggled to China. ${ }^{72}$ The British, in short, facilitated the illicit trade in opium and undermined prohibition.

In 1813 Emporer Jiaqing (1796-1820) - whilst repeating the earlier prohibitions - characterised opium as 'poisoning and confusing people's minds' and suppressing economic livelihoods. Then, in 1822, Emperor Daoguang (1821-50) blamed opium for damaging the customs and 'popular morale' of the Chinese peoples. The Emperor issued a further anti-opium edict in 1830 which described the drug as damaging to health. ${ }^{73}$

The amount of opium smuggled from India increased. This inflated both Chinese consumption and the outflow of silver, which in turn deflated the Chinese 
Windle, J. (2013). 'How the East Influenced Drug Prohibition'. The International History Review, 35(5), pp. 1185-1199. Pre-publication copy

economy and further increased opposition to the trade, ${ }^{74}$ especially as peasants had to pay greater taxes to tackle the deficit. Many came to view opium as an alien drug exploited by the West to weaken China. ${ }^{75}$ The Imperial regime and political elite were additionally concerned by British influence in China and the corruption of state institutions by smugglers. ${ }^{76}$

To cut the supply China interdicted opium in transit, arrested dealers, and forcefully eradicated opium poppies. ${ }^{77}$ These efforts were, however, unsuccessful at reducing consumption. Then in 1839 the Emperor enlisted Lin Tse-hsu who famously decided to tackle opium consumption on three fronts. Firstly, consumers were threatened with severe penalties until abstinence was achieved, after which they would receive medical treatment. Secondly, Chinese smuggling and distribution networks were targeted by law enforcement and stricter punishments were imposed, including the death sentence. ${ }^{78}$ Lastly, the Commissioner sought to cut foreign supplies by appealing to the British for support. When diplomacy failed, Commissioner Lin interdicted and destroyed 15,000 chests containing approximately ninety-five tons of opium from British and, to a much lesser extent, US merchants. ${ }^{79}$

As the Chinese market was economically important to British India the enforcement of the import ban resulted in a three-year conflict. A defeated China was forced to cede Hong Kong and pay compensation for damages done to British opium merchants. The illicit trade continued as before, albeit at an increased level. ${ }^{80}$

In 1858, the Chinese Government - after fighting a Second 'Opium War' with the British and French - legalised the importation of opium by including it on a list of goods subject to import tariff. ${ }^{81}$ Then during the 1860s the Emperor approved the taxation of opium production in Yunnan to fund the suppression of the Panthay Uprising. The Imperial regime, however, remained officially opposed to opium consumption. ${ }^{82}$ Several other provinces followed Yunnan's example and de facto legalisation preceded the official repeal of prohibition in the mid-1880s. ${ }^{83}$ At the risk of sounding repetitive, the import prohibition was repealed half a century before the passing of the Harrison Act.

By 1905 China was the world's leading source of opium ${ }^{84}$ and possessed a significant consumer population. ${ }^{85}$ The political elite returned to traditional reservations about opium ${ }^{86}$ by again calling the drug a threat to national productivity and health. ${ }^{87}$ Many saw the history of foreign trade as a sign of Chinese weakness in 
Windle, J. (2013). 'How the East Influenced Drug Prohibition'. The International History Review, 35(5), pp. 1185-1199. Pre-publication copy

the international arena. Others saw opium consumers as a limitation on modernisation. ${ }^{88}$

In September 1906 an Imperial Decree declared the suppression of opium production, trade, and consumption. ${ }^{89}$ By ceasing to export Indian opium to China the British Government allowed China to prohibit a trade it had 'opposed for more than a century'. ${ }^{90}$ The domestic intervention was centred upon a highly repressive incarnation of law enforcement which pushed many farmers deeper into poverty. ${ }^{91}$ It was, however, successful in terms of drug policy and in 1917 a Chinese-British joint investigation declared all provinces of China 'opium-free'. ${ }^{92}$ While the fragmentation of the state was to make prohibition unsustainable until after the 1949 Communist Revolution opium prohibition remained an objective for many, but by no means for all, Chinese politicians and peoples. ${ }^{93}$

The five case studies have shown how prohibitions were enforced in a number of Eastern states while Western nations were routinely trading opium. Furthermore, it has shown how Western powers directly overturned or significantly undermined longstanding prohibitions.

\section{Western missionaries in China}

As already discussed, Western missionaries were instrumental in constructing both national and international prohibition, as part of a larger network of moral entrepreneurs and professional bodies. This section asks: could the thousands of Chinese who befriended Western missionaries, ${ }^{94}$ and joined their congregations (sometimes to use their detoxification treatments), ${ }^{95}$ have influenced Western missionaries' perceptions of opium?

During the early nineteenth century, Western missionaries began proselytising Christianity in China. They built schools, orphanages, and hospitals. These early missionaries also collaborated in the opium trade. Many legitimately used opium as medicine, as was the norm with Chinese doctors. Others traded the drug as a means of funding their mission and/or supplied addicts on condition they attended prayer meetings. ${ }^{96}$ A large number simply arrived in China as passengers in ships carrying opium. ${ }^{97}$ Even missionaries with no connection to the trade were perceived as culpable by many who failed to differentiate between Westerners selling drugs or religion. ${ }^{98}$ 
Windle, J. (2013). 'How the East Influenced Drug Prohibition'. The International History Review, 35(5), pp. 1185-1199. Pre-publication copy

Missionaries became aware that the stigma attached to opium and opium traders hindered their ability to proselytise when 'crowds heckled them about the opium problem as they attempted to preach in the countryside'. Many missionaries were, therefore, reluctant to admit being citizens of countries which traded opium. ${ }^{99}$ The drug also became a convenient scapegoat for their failures to convert a significant number of Chinese after decades of religious proselytising. ${ }^{100}$ This said, many missionaries no doubt perceived all intoxication as morally wrong and therefore felt it their duty to help the Chinese people rid themselves of opium. ${ }^{101}$ Nonetheless, as they came from countries which generally tolerated opium consumption, ${ }^{102}$ it is possible that many individual perceptions of opium were changed by experiences in China and interaction with Chinese prohibitionists.

During the mid/late nineteenth century, many missionaries began to lobby their home governments to cease trading opium to China whilst attempting to force sobriety on their Chinese congregations. These missionaries were instrumental in the spread of prohibition in the West. They came back from China and presented evidence they had collected of the negative effects of opium on the Chinese peoples. These reports were influential in gradually developing 'compassion for China's opium-addicted masses ${ }^{103}$ and changing attitudes to the harmfulness of opium and perceptions of addiction. ${ }^{104}$

While many missionaries believed they were culturally superior to locals and 'came to change, not be changed', ${ }^{105}$ it is unlikely that none were impacted by their involvement with locals. Kathleen Lodwick shows how 'Christians in Britain had been lectured on the immorality of the trade by Chinese' prohibitionists. ${ }^{106}$ For example, in 1881, Li Hung-chang - a leading Chinese bureaucrat and diplomat - told British missionaries that the Chinese Emperor was opposed to opium and 'never desired his empire to thrive upon the lives or infirmities of his subjects'. ${ }^{107}$

Missionaries also provided a conduit for Chinese peoples to communicate their prohibitionist message to peoples and governments in the West by printing opinion articles articulating 'elite and popular Chinese opinion' of the harmfulness of opium. ${ }^{108}$ Chinese citizens and officials would also write to lobby groups in the West to describe the harm opium was doing to the Chinese state and peoples. These communications presented domestic moral entrepreneurs evidence to support their anti-opium campaigns. ${ }^{109}$ 
Windle, J. (2013). 'How the East Influenced Drug Prohibition'. The International History Review, 35(5), pp. 1185-1199. Pre-publication copy

Less politically, Jonathon Spence notes many missionaries who had befriended locals simply 'commiserated' with them about opium consumption and addiction. ${ }^{110}$ In terms of medical opinion, in 1897, 106 Western missionary doctors working in China were asked their views on opium. The majority suggested that the Chinese they met generally perceived consumption as damaging to individual health and society. ${ }^{111}$

Some Chinese moral entrepreneurs established Anti-Opium Societies in China to lobby for the reintroduction of prohibition. ${ }^{12}$ The general argument of these moral entrepreneurs was a continuation of the long-held view of opium consumption and trade as economically and physically damaging to individual consumers and the state. ${ }^{113}$

This section should not be interpreted as suggesting that prohibition would not have developed in the West without missionary interaction with Eastern prohibitionists. As discussed at the beginning of this article, prohibition was the result of a convergence of factors. The prohibition of opium and opiates was linked to, and possibly an extension of, the Progressive Movement in the United States. The move towards prohibition also reflected developments in medicine and, issues of foreign policy, racism, and class. It also reflected the economic and institutional self-interest of moral entrepreneurs and professional bodies. The lateness of prohibition may additionally be a sign of cultural fear in the United States of too strong a state. ${ }^{114}$ This section simply posits that Chinese prohibitionists may have influenced Western moral entrepreneurs, who were in turn important actors in the construction of prohibition in the West.

\section{Conclusion}

That prohibition is an American construct is difficult to defend when we consider that the first American state to prohibit the smoking of opium did so over 500 years after Siam (Thailand) first prohibited the drug. By the time the United States first passed a federal prohibition, China was on its second round of prohibition: the previous one, enacted in 1799 , had been systematically undermined by Western powers.

To conclude let us revisit a quote from Nadelmann: 
Windle, J. (2013). 'How the East Influenced Drug Prohibition'. The International History Review, 35(5), pp. 1185-1199. Pre-publication copy

[T]he nature of the global drug control regime reflected the predominance of the United States and Europe in establishing global norms concerning the selection and appropriate uses of psychoactive substances. Some Asian states, for instance, might have opted for a different global regime that legitimized the use of opium . . . the global drug enforcement regime reflected the desire and capacity of the United States to impose its drug-related norms on the rest of the world. ${ }^{115}$

Some Asian states may have sought to keep opium legal; however, the history of prohibition in the five cases reviewed suggests otherwise. It was, after all, Western nations who overturned prohibitions in Burma and Viet Nam, and undermined prohibitions in Siam (Thailand) and China.

The departure point between the United States and Asian states may be in the final sentence of Nadelmann's quote: the United States had the 'desire and capacity' to impose prohibition and evolve a national construct into an international one, whereas none of the case studies discussed above did. China, for example, was not only struggling to impose prohibition on its own citizens, but required the cooperation of Western states which had previously obstructed prohibition. (That China never had the power - or possibly desire - to spread its construct outwards is a blessing considering the brutality of early twentieth-century Chinese opium bans.)

The United States did not construct prohibition but it did globalise its prohibitionist policies and counter-narcotic measures. ${ }^{116}$ It would be difficult to argue against the influence of the United States, and to a lesser extent some Western European countries, on the global prohibition regime and, consequentially, national laws and responses. ${ }^{117}$ Since the early 1900s, the United States has been one of the key proponents of prohibition on the international stage ${ }^{118}$ and has used the League of Nations and later the United Nations as a vehicle for 'the export of prohibitive ideals'. ${ }^{119}$ The United States has, for example, helped write and gain acceptance for almost all major international drug-control conventions, ${ }^{120}$ and has successfully lobbied for the exportation of US law-enforcement techniques and strategies, often by training and/or funding their counterparts. ${ }^{121}$ 
Windle, J. (2013). 'How the East Influenced Drug Prohibition'. The International History Review, 35(5), pp. 1185-1199. Pre-publication copy

The current international regime may then reflect the 'the desire and capacity of the United States to impose its drug-related norms on the rest of the world'. ${ }^{122}$ This, however, is not the same as prohibition being an American or Western construct. David Bewley-Taylor may also be correct that the global regime is centred upon an 'American prohibitive model', ${ }^{123}$ but again this is not the same as prohibition being an American or Western construct.

A major similarity between the United States and China (and probably most nations) is that they allowed 'realist concerns for wider national interest' ${ }^{\text {'24 }}$ to trump drug-control objectives based on morality, religion, or concerns for health. For example, Chinese leaders facilitated the opium trade to fund counter-insurgency during the Panthay Rebellion (1856-73) and conflicts during the Warlord Era (191135). ${ }^{125}$ Many Chinese prohibitionists moved between economic realism and morality by advocating the collection of opium revenues in the short term whilst lobbying for prohibition in the long term. ${ }^{126}$ American state organisations have similarly exploited the illicit drugs trade to further political and economic objectives in Afghanistan, Laos, and Viet Nam. ${ }^{127}$ Once entrenched, however, the ideology of prohibition never really left the United States or China: prohibition remained the official end goal.

Lastly, by calling the current global drug-prohibition regime a form of 'cultural imperialism' ${ }^{\prime 28}$ may be to ignore the Eastern foundation of prohibition. It may be cultural imperialism to believe that Western moral entrepreneurs constructed the concept of prohibition when a number of Eastern prohibitions against intoxicating substances were enforced centuries before the United States Harrison Act. As importantly, it is likely that some of the most prominent moral entrepreneurs were themselves influenced by Chinese prohibitionists. Or are we to believe that missionaries travelled to China on opium clippers and returned opponents of the drug, without ever being influenced by the people they were interacting with?

The somewhat distorted view of the 'prohibition as an American construct' thesis is best illustrated in the following quote:

In the Asian, African, and Caribbean countries in which opium or cannabis use was prevalent, members of the elite tended not to partake; indeed, their moral views regarding drug use more often resembled those of Western elites. ${ }^{129}$ 
Windle, J. (2013). 'How the East Influenced Drug Prohibition'. The International History Review, 35(5), pp. 1185-1199. Pre-publication copy

Corrected, this sentence would read: 'Western elites' moral view of drug use more often resembled those of early Eastern elites.'

\footnotetext{
${ }^{1}$ P. Andreas and E. A. Nadelmann, Policing the Globe: Criminalization and Crime Control in International Relations (Oxford, 2006).

${ }^{2}$ M. Woodiwiss and D. Bewley-Taylor, The Global Fix: The Construction of a Global
}

Enforcement Regime (Amsterdam, 2005), 5.

${ }^{3}$ K. Bruun, L. Pan, and I. Rexed, The Gentlemen's Club: International Control of Drugs and Alcohol (London, 1975); E. Nadelmann, 'Global Prohibition Regimes: The Evolution of Norms in International Society', International Organization, xliv, no. 4 (1990), 479-526 (511).

${ }^{4}$ Nadelmann, 'Global Prohibition Regimes', 511.

${ }^{5}$ Ibid. See also Bruun et al., The Gentlemen's Club.

${ }^{6}$ Andreas and Nadelmann, Policing the Globe; Nadelmann, 'Global Prohibition Regimes'.

${ }^{7}$ D. Bewley-Taylor, The United States and International Drug Control, 1909-1997 (London, 1999).

${ }^{8}$ K. Lodwick, Crusaders against Opium: Protestant Missionaries in China, 1874-1917 (Lexington, 1996); W. McAllister, Drug Diplomacy in the Twentieth Century: An International History (Oxford, 2000).

${ }^{9}$ Lodwick, Missionaries.

${ }^{10}$ J. B. Brown, 'Politics of the Poppy: The Society for the Suppression of the Opium Trade, 1874-

1916', Journal of Contemporary History, viii, no. 3 (1973), 97-111. This remains the broad theoretical argument in favour of supply reduction: K. Murji, 'Drug Enforcement Strategies', The Howard Journal of Criminal Justice, xxxii, no. 3 (1993), 215-30.

${ }^{11}$ Cited in Nadelmann, 'Global Prohibition Regimes'.

${ }^{12}$ G. Blue, 'Opium for China: The British Connection' in T. Brook and B. T. Wakabayashi (eds), Opium Regimes: China, Britain, and Japan, 1839-1952 (London, 2000).

${ }^{13}$ Nadelmann, 'Global Prohibition Regimes', 524. In a similar process abolitionists used the writings of witnesses of the slave trade in Africa to lobby the public to support the prohibition of slavery.

${ }^{14}$ J. Windle, 'Insights for Contemporary Drug Policy: A Historical Account of Opium Control in India and Pakistan', Asian Journal of Criminology, vii, no. 1 (2012), 55-74.

${ }^{15}$ Ibid.

${ }^{16}$ McAllister, Drug Diplomacy.

${ }^{17}$ D. F. Musto, The American Disease: Origins of Narcotic Control (Oxford, 1999).

${ }^{18}$ Bruun et al., The Gentlemen's Club; McAllister, Drug Diplomacy; Musto, The American Disease; W. O. Walker, 'US Narcotics Foreign Policy in the 20th Century: An Analytical Overiew' in R. F. Perl, Drugs and Foreign Policy: A Critical Review (Oxford, 1994).

${ }^{19}$ Musto, The American Disease; Walker, 'US Narcotics Foreign Policy'.

${ }^{20}$ Bewley-Taylor, The United States.

${ }^{21}$ Bruun et al., The Gentlemen's Club; McAllister, Drug Diplomacy; Musto, The American Disease;

Windle, 'Insights for Contemporary Drug Policy'.

${ }^{22}$ Bewley-Taylor, The United States.

${ }^{23}$ Andreas and Nadelmann, Policing the Globe; Bewley-Taylor, The United States.

${ }^{24}$ Musto, The American Disease.

${ }^{25}$ Bewley-Taylor, The United States, 11; McAllister, Drug Diplomacy.

${ }^{26}$ Bewley-Taylor, The United States.

${ }^{27}$ Andreas and Nadelmann, Policing the Globe.

${ }^{28}$ Bewley-Taylor, The United States; C. Reinarman, 'The Social Construction of Drug Scares' in P. A. Adler and P. Adler (eds) Constructions of Deviance: Social Power, Context, and Interaction (Belmont, 1994). The parallel movement to prohibit the consumption of cocaine shared these motivating factors: Musto, The American Disease.

${ }^{29}$ D. T. Courtwright, Dark Paradise: Opiate Addiction in America before 1940 (Cambridge, 1982); also Reinarman, 'Social Construction'.

${ }^{30}$ F. Dikötter, L. P. Laamann, and Z. Xun, Narcotic Culture: A History of Drugs in China, (Hong Kong, 2004). See also Musto, The American Disease.

${ }^{31}$ Dikötter et al., Narcotic Culture, 94.

32 Reinarman, 'Social Construction', 157.

${ }^{33}$ Musto, The American Disease; Nadelmann, 'Global Prohibition Regimes'. 
${ }^{34}$ Blue, 'Opium for China'.
${ }^{35}$ Nadelmann, 'Global Prohibition Regimes'; H. G. Levine and C. Reinarman, 'From Prohibition to Regulation: Lessons from Alcohol Policy for Drug Policy', The Milbank Quarterly, 1xix, no. 3 (1991), 461-94.

${ }^{36}$ Nadelmann, 'Global Prohibition Regimes'.

${ }^{37}$ Musto, The American Disease.

${ }^{38}$ L. J. Alston, R. Dupr_e, and T. Nonnenmacher, 'Social Reformers and Regulation: The Prohibition of Cigarettes in the United States and Canada', Explorations in Economic History, xxxix, no. 4 (2002), 425-45; Levine and Reinarman, 'From Prohibition to Regulation'.

${ }^{39}$ C. Reinarman and H. G. Levine, 'Crack in Context: America's Latest Demon Drug' in C. Reinarman and H. G. Levine (eds), Crack in America: Demon Drugs and Social Justice, (London, 1997).

${ }^{40}$ Ibid.

${ }^{41}$ Levine and Reinarman, 'From Prohibition to Regulation'.

${ }^{42}$ R. Renard, 'The Making of a Problem: Narcotics in Mainland Southeast Asia' in D. McCaskill and K. Kampe (eds), Development or Domestication (Chaing Mai, 1997).

${ }^{43}$ Ibid.

${ }^{44}$ P. Jinawat, 'Thailand Country Paper'. Paper presented at 'Alternative Development: Sharing Good Practices Facing Common Problems. Regional Seminar on Alternative Development for Illicit Crop Eradication Policies, Strategies and Actions' (2001), Myanmar; Renard, 'Narcotics in Mainland Southeast Asia'.

${ }^{45}$ A. McCoy, The Politics of Heroin: CIA Complicity in the Global Drug Trade, Afghanistan, Southeast Asia, Central America (Chicago, 2003).

46 Jinawat, 'Thailand Country Paper'. See also Renard, 'Narcotics in Mainland Southeast Asia'.

${ }^{47}$ R. Renard, Opium Reduction in Thailand, 1970-2000: A Thirty Year Journey (Chaing Mai, 2001); Renard, 'Narcotics in Mainland Southeast Asia'. See also McCoy, The Politics of Heroin.

${ }^{48}$ League of Nations, Commission of Enquiry into the Control of Opium-Smoking in the Far East:

Report to the Council: Detailed Memoranda on Each Territory Visited by the Commission, C.635.M.254.1930 (1930).

${ }^{49}$ League of Nations, Control of Opium-Smoking in the Far East.

${ }^{50}$ Renard, Opium Reduction in Thailand.

${ }^{51}$ Ibid.; Renard, 'Narcotics in Mainland Southeast Asia'.

${ }^{52}$ McCoy, The Politics of Heroin.

${ }^{53}$ M. Vaughn, F. Huang, and C. Ramirez, 'Drug Abuse and Anti-Drug Policy in Japan', British Journal of Criminology, xxxv, no. 4 (1995), 491-524 (494).

${ }^{54}$ Similar treaties had been signed with Holland and Russia: B.T. Wakabayashi, 'From Peril to Profit: Opium in Late-Edo to Meiji Eyes' in T. Brook and B. T. Wakabayashi (eds), Opium Regimes: China, Britain, and Japan, 1839-1952 (London, 2000).

${ }^{55}$ Ibid.; Vaughn et al., 'Anti-Drug Policy in Japan'.

${ }^{56}$ Ibid.

${ }^{57} \mathrm{McC}$ cy, The Politics of Heroin, 110; Hoa Nguyen, Legislative Implementation by Vietnam of Its Obligations under the United Nations Drug Control Conventions (PhD diss., University of Wollongong, Australia, 2008).

${ }^{58}$ Nguyen, Vietnam.

${ }^{59}$ McCoy, The Politics of Heroin.

${ }^{60}$ Nguyen, Vietnam.

${ }^{61}$ McCoy, The Politics of Heroin, 110; Nguyen, Vietnam.

${ }^{62}$ A.-J. Rapin, H. Dao, and H. Pham, Highlands of Northern Vietnam (Bangkok, 2003).

${ }^{63}$ McCoy, The Politics of Heroin.

${ }^{64}$ Renard, 'Narcotics in Mainland Southeast Asia', 319.

${ }^{65}$ T. Brook and B. T. Wakabayashi, 'Opium's History in China' in T. Brook and B. T. Wakabayashi (eds), Opium Regimes: China, Britain, and Japan, 1839-1952 (London, 2000).

${ }^{66}$ F. Farley, 'Commissioner Lin and the Opium', History Today, xxvii, no. 2 (1977),

73-82; H. Lu and B. Liang, 'Legal Responses to Trafficking in Narcotics and Other Narcotic Offenses in China', International Criminal Justice Review, xviii, no. 2 (2008), 212-28; McCoy, The Politics of Heroin; Z. Yongming, Anti-Drug Crusades in Twentieth-Century China: Nationalism, History, and State Building (Oxford, 1999).

${ }^{67}$ Lu and Liang, 'Legal Responses'.

${ }^{68}$ M. Booth, The Dragon Syndicate (Kent, 2000).

${ }^{69}$ Yongming, Anti-Drug Crusades, 13. 
Windle, J. (2013). 'How the East Influenced Drug Prohibition'. The International History Review, 35(5), pp. 1185-1199. Pre-publication copy

${ }^{70}$ T. Pietschmann, M. Tullis, and T. Leggett, A Century of International Drug Control (Vienna, 2010).

${ }^{71}$ Yongming, Anti-Drug Crusades.

72 J. Windle, 'Ominous Parallels and Optimistic Differences: Opium in China and Afghanistan', Law, Crime and History, ii, no. 1 (2011), 141-64.

${ }^{73}$ Cited in Yongming, Anti-Drug Crusades, 13-14.

${ }^{74}$ D. Bello, 'The Venomous Course of Southwestern Opium: Qing Prohibition in Yunnan, Sichuan, and Guizhou in the Early Nineteenth Century', The Journal of Asian Studies, 1xii, no. 4 (2003), 110942; Brook and Wakabayashi, 'Opium's History in China'; Farley, 'Commissioner Lin'.

${ }^{75}$ F. Wakeman, The Fall of Imperial China (New York, 1977).

${ }^{76}$ J. Madancy, 'Unearthing Popular Attitudes toward the Opium Trade and Opium Suppression in Late Qing and Early Republican Fujian', Modern China, xxvii, no. 4 (2001), 436-83; Yongming, Anti-Drug Crusades.

${ }^{77}$ Madancy, 'Unearthing Popular Attitudes'; See Bello, 'Qing Prohibition’.

${ }^{78}$ Lodwick, Missionaries; Wakeman, Imperial China.

${ }^{79}$ Wakeman, Imperial China.

${ }^{80}$ Farley, 'Commissioner Lin'; Windle, 'Opium in China and Afghanistan'.

${ }^{81}$ Yongming, Anti-Drug Crusades.

${ }^{82}$ Brown, 'Politics of the Poppy'.

${ }^{83}$ Yongming, Anti-Drug Crusades.

${ }^{84}$ Brown, 'Politics of the Poppy'; Windle, 'Insights for Contemporary Drug Policy'.

${ }^{85}$ See Government of China, Memorandum Respecting the Prohibition of Opium Smoking in China (1907), in British National Archives, Kew London: FO 881 8809; J. Spence, 'Opium Smoking in Ching China' in F. Wakeman and C. Grant, Conflict and Control in Late Imperial China (Berkeley, 1975).

${ }^{86}$ Brown, 'Politics of the Poppy'.

${ }^{87}$ A. Baumler, 'Opium Control Versus Opium Suppression' in T. Brook and B. T. Wakabayashi (eds), Opium Regimes: China, Britain, and Japan, 1839-1952 (London, 2000).

${ }^{88}$ Lodwick, Missionaries.

${ }^{89}$ Government of China, Memorandum Respecting the Prohibition of Opium Smoking.

${ }^{90}$ T.D. Reins, 'Reform, Nationalism and Internationalism: The Opium Suppression Movement in China and the Anglo-American Influence, 1900-1908', Modern Asian Studies, xxv, no. 1 (1991), 10142 (102).

${ }^{91}$ Windle, 'Opium in China and Afghanistan'.

${ }^{92}$ Foreign Policy Association, China. Committee on Traffic in Opium. October 24th 1924 (1924), [UK National Archives] FO371/10345; International Anti-Opium Association, The Annual Report, 4(1) (1924), FO 2283368.

${ }^{93}$ Baumler, 'Opium Control'; Madancy, 'Unearthing Popular Attitudes'; E. Slack, 'The National AntiOpium Association and the Guomindang State, 1924-1937' in T. Brook and B. Wakabayashi (eds), Opium Regimes: China, Britain, and Japan, 1839-1952, (London, 2000); Windle, 'Opium in China and Afghanistan'.

${ }^{94}$ J. Spence, The Search for Modern China (London, 1990).

${ }^{95}$ Madancy, 'Unearthing Popular Attitudes'.

${ }^{96}$ Booth, The Dragon Syndicate.

${ }^{97}$ Lodwick, Missionaries; McAllister, Drug Diplomacy.

${ }^{98}$ Brown, 'Politics of the Poppy'.

${ }^{99}$ Lodwick, Missionaries. See also Madancy, 'Unearthing Popular Attitudes'.

${ }^{100}$ Blue, 'Opium for China: The British Connection'; Lodwick, Missionaries; McAllister, Drug Diplomacy.

${ }^{101}$ Bewley-Taylor, The United States.

${ }^{102}$ V. Berridge and G. Edwards, Opium and the People: Opiate Use and Policy in 19th and Early 20th Century Britain (London, 1998); Musto, The American Disease.

${ }^{103}$ Nadelmann, 'Global Prohibition Regimes', 524.

104 Blue, 'Opium for China'.

${ }^{105}$ C. C. Chin, 'Beneficent Imperialists: American Women Missionaries in China at the Turn of the

Twentieth Century', Diplomatic History, xxvii, no. 3 (2003), 327-52.

${ }^{106}$ Lodwick, Missionaries, 69; M. Booth, Opium: A History (London, 1997).

${ }^{107}$ Cited in Lodwick, Missionaries, 28.

${ }^{108}$ Blue, 'Opium for China', 38.

${ }^{109}$ Lodwick, Missionaries, 69; Booth, Opium.

110 Spence, The Search for Modern China, 209. 
${ }^{111}$ Lodwick, Missionaries.

112 Madancy, 'Unearthing Popular Attitudes'; Yongming, Anti-Drug Crusades.

113 Yongming, Anti-Drug Crusades.

${ }^{114}$ Musto, The American Disease.

115 Nadelmann, 'Global Prohibition Regimes', 511.

${ }^{116}$ Andreas and Nadelmann, Policing the Globe.

${ }^{117}$ Bewley-Taylor, The United States; J. Gerber and E. L. Jensen, Drug War, American Style: The Internationalization of Failed Policy and Its Alternatives (Oxford, 2001); McAllister, Drug Diplomacy; Musto, The American Disease; Nadelmann, 'Global Prohibition Regimes'.

${ }^{118}$ Andreas and Nadelmann, Policing the Globe; E. Epstein, Agency of Fear: Opiates and Political Power in America (London, 1990); Renard, 'Narcotics in Mainland Southeast Asia', 308.

${ }^{119}$ Bewley-Taylor, The United States, 94.

${ }^{120}$ H. G. Levine, 'Global Drug Prohibition: Its Uses and Crises', International Journal of Drug Policy, xiv, no. 2 (2003), 145-53.

${ }^{121}$ Andreas and Nadelmann, Policing the Globe, 131.

122 Nadelmann, 'Global Prohibition Regimes', 511; Renard, 'Narcotics in Mainland Southeast Asia'.

${ }^{123}$ Bewley-Taylor, The United States, 46.

124 Ibid., 217.

${ }^{125}$ K. Meyer and T. Parssinen, Webs of Smoke: Smugglers. Warlords, Spies, and the History of the International Drug Trade (London, 1998); Windle, 'Opium in China and Afghanistan'.

${ }^{126}$ Reins, 'The Opium Suppression Movement in China', 106

${ }^{127} \mathrm{McC}$ oy, The Politics of Heroin.

${ }^{128}$ Bewley-Taylor, The United States, 180.

${ }^{129}$ Nadelmann, 'Global Prohibition Regimes', 510. 